\title{
ANALISIS HARGA SAHAM PADA PERUSAHAAN ASURANSI YANG GO PUBLIK DI BURSA EFEK INDONESIA PERIODE 2005 - 2009
}

\author{
Oleh: \\ Sri Marniyati Amarullah \\ Syamsul Hadi \\ Fakultas Ekonomi Universitas Muhammadiyah Malang \\ E-mail/No. HP: marni_am@yahoo.co.id/082195403527
}

\begin{abstract}
The purpose of this study was to measure the influence of Price Earning Ratio (PER), Leverage Ratio (LR), Return On Equity (ROE), Price to Book Value (PBV) on Stock price in the insurance company. The analysis used the quantitative analysis of multiple linear regression model using ordinary least squares (OLS). From the results, it could be explain that the variables price earning ratio, leverage ratio, return on equity and price to book value has a significant influence on Stock price together was amounted to F calculated 3,896 > F table 2,61. From the $t$ test, each variables that significantly influence the Stock price were PER (2,108 $t$ calculate > t-table 2,021), ROE (2,654t calculated > t-table 2,021. On the contrary, the variables that were not impact significantly were LR $(1,318 t$ calculated $<$ t-table 2,021) and PBV (-3,141 t calculated > t-table -2,021). Based on these results, obtained empirical evidence that could be considerated towards a more in-depth study on Stock price. It would be interesting if further study pay attention to the technical factors as well as policies set by the government.
\end{abstract}

Keywords: insurance, stock price, price earning ratio, and leverage ratio

\begin{abstract}
Abstrak
Tujuan penelitian ini adalah untuk mengetahui besar pengaruh Price Earning Ratio (PER), Leverage Ratio (LR), Return on Equity (ROE) dan Price to Book Value (PBV) terhadap harga saham pada perusahaan asuransi. Analisis yang digunakan yakni analisis kuantitatif model regresi linear berganda dengan menggunakan metode Ordinary Least Square (OLS). Dari hasil penelitian dapat dijelaskan bahwa secara bersama-sama variabel price earning ratio, leverage ratio, return on equity dan price to book value mempunyai pengaruh yang signifikan terhadap harga saham sebesar F hitung 3,896 > F tabel 2,61. Dilihat dari uji $t$, masing-masing variabel yang berpengaruh signifikan terhadap harga saham adalah PER ( $t$ hitung 2,108 > t-tabel 2,021) dan ROE ( $t$ hitung 2,654 > ttabel 2,021). Sedangkan variabel yang berpengaruh tidak signifikan terhadap harga saham adalah LR ( $t$ hitung 1,318 < t-tabel 2,021) dan PBV ( t hitung -3,141 $<$ t-tabel 2,021). Berdasarkan hasil penelitian ini, diperoleh bukti empiris yang bisa dijadikan pertimbangan kearah penelitian yang lebih mendalam tentang harga saham. Akan lebih menarik apabila penelitian selanjutnya memperhatikan faktor-faktor teknikal maupun kebijakan yang ditetapkan pemerintah.
\end{abstract}

Kata Kunci: asuransi, harga saham, price earning ratio, leverage ratio 


\section{PENDAHULUAN}

Pelaksanaan Zona Perdagangan bebas Asean yang di kenal dengan Asean Free Trade Area (AFTA) 2003 dan besarnya pasar yang demikian menjanjikan di kawasan-kawasan Asia terutama Asia Tenggara telah mendorong terjadinya penetrasi perusahaan Multinasional yang semakin meningkatkan intensitasnya belakangan ini, terutama sejak dan dalam masa-masa pemulihan ekonomi. Dukungan dana yang kuat dan mulai jenuhnya pasar Eropa dan Amerika menjadikan mereka mengalihkan perhatian ke kawasan padat penduduknya di Asia dan negara-negara dengan perekonomian yang terus tumbuh.

Indonesia sebagai salah satu negara di kawasan Asia dengan jumlah penduduk terbesar, merupakan pangsa pasar yang berpotensial dan menjadi salah satu pilihan bagi perusahaan-perusahaan global di bidang barang dan jasa untuk mengembangkan usahanya. Hal ini menjadi suatu keadaan yang tidak dapat di hindari karena perekonomian suatu negera dalam era globalisasi tidak hanya menyangkut kegiatan usaha atau pasar di dalam negeri, melainkan sudah menyangkut pasar di luar negeri. Kehidupan perekonomian sudah menyangkut hubungan perekonomian dengan negera lain.

Kondisi perekonomian Indonesia yang pada periode 1996 1997 tumbuh sekitar rata-rata 6\% pertahunnya telah mendorong tumbuhnya dan perkembangan berbagai industri. Kondisi ini selanjutnya memacu pertumbuhan sektor usaha jasa asuransi rata-rata mencapai 23,6 \% setiap tahunnya.

Kondisi perekonomian yang kemudian memburuk sejak tahun 1997 yang berlanjut dengan krisis ekonomi, berdampak negatif pada berbagai sektor usaha yang selanjutnya berpengaruh pada pertumbuhan jasa keuangan. Namun bagi industri jasa asuransi dampak negatif tersebut tidak separah yang dialami industri keuangan misal Perbankan. Pertumbuhan industri jasa asuransi dari tahun ke tahun terus mengalami kenaikan yang cukup signifikan yakni sekitar $30 \%$.

Sebagai penanam modal yang menanamkan sahamnya pada saham biasa, investor harus mampu melakukan perhitungan dan analisis saham untuk mengetahui tingkat 
pengembalian (return) dan tingkat

Penilaian saham dapat resiko karena saham biasa dilakukan dengan Price Earning mempunyai tingkat resiko yang lebih tinggi daripada bentuk investasi lainnya. Dengan kemampuan melakukan perhitungan dan analisis saham tersebut, investor akan tahu kapan ia harus membeli saham dan kapan harus menjualnya kembali. Apabila saham mengalami undervalue, yaitu harga saham lebih rendah dari nilai wajarnya maka ada kemungkinan untuk membeli saham tersebut, tetapi apabila saham tersebut mengalami overvalue, yaitu harga saham berada di atas nilai wajarnya maka ada kemungkinan untuk menjual saham yang dimiliki.

Krisis Finansial global yang terjadi pada pertengahan September 2008 dan dimulai karena Subprime Mortgage di Amerika Serikat tersebut berdampak pada kinerja industri asuransi di Indonesia selama tahun 2008 sampai 2009. Akibat krisis ini dimana harga saham jatuh tajam, berdampak pada turunnya harga unit link, pernurunan harga unit hampir mencapai $60 \%$, akibatnya banyak investor yang hasil investasinya tidak seperti yang diharapkan. Ratio (PER) dan Price to Book Value (PBV), karena kedua ukuran tersebut sangat berpengaruh terhadap nilai suatu saham. Bagi investor, PER digunakan untuk memprediksi kemampuan perusahaan dalam menghasilkan laba di masa datang. Sedangkan PBV, apabila harga pasar berada di bawah nilai bukunya, investor memandang bahwa perusahaan tersebut tidak cukup potensial.

Hasil usaha yang optimal akan dapat dicapai dengan menggunakan keseluruhan modal perusahaan yang diinvestasikan dalam aktiva untuk menghasilkan keuntungan yang terlihat pada Leverage Ratio (LR) perusahaan, sedangkan penghasilan yang tersedia bagi para pemilik atau modal yang diinvestasikan dalam perusahaan diukur dengan Return On Equity (ROE).

\section{Kondisi}

perekonomian Indonesia yang pada periode 1996 1997 tumbuh sekitar rata-rata 6\% pertahunnya telah mendorong tumbuhnya dan perkembangan berbagai industri. Kondisi ini selanjutnya memacu pertumbuhan 
sektor usaha jasa asuransi rata-rata mencapai $23,6 \%$ setiap tahunnya.

Kondisi perekonomian yang kemudian memburuk sejak tahun 1997 yang berlanjut dengan krisis ekonomi, berdampak negatif pada berbagai sektor usaha yang selanjutnya berpengaruh pada pertumbuhan jasa keuangan. Namun bagi industri jasa asuransi dampak negatif tersebut tidak separah yang dialami industri keuangan misal Perbankan. Pertumbuhan industri jasa asuransi dari tahun ke tahun terus mengalami kenaikan yang cukup signifikan yakni sekitar $30 \%$.

\section{Tabel 1. Harga Saham Perusahaan Asuransi Periode 2005-2009}

\begin{tabular}{lccccc}
\hline \multicolumn{1}{c}{ Perusahaan } & \multicolumn{5}{c}{ Tahun } \\
\cline { 2 - 6 } & 2005 & 2006 & 2007 & 2008 & 2009 \\
\hline PT. ABDA & 200 & 220 & 220 & 200 & 300 \\
PT. AHAP & 135 & 90 & 225 & 86 & 114 \\
PT. ASBI & 370 & 340 & 345 & 400 & 355 \\
PT. ASDM & 240 & 175 & 190 & 114 & 180 \\
PT. ASRM & 1000 & 1010 & 790 & 610 & 900 \\
PT. LPGI & 265 & 340 & 540 & 340 & 455 \\
PT. MREI & 165 & 150 & 225 & 174 & 285 \\
PT. PNIN & 265 & 280 & 330 & 149 & 255 \\
PT. PNLF & 135 & 165 & 195 & 83 & 140 \\
\hline
\end{tabular}

Sumber : Bursa Efek Indonesia tahun 2009

Krisis Finansial global yang terjadi pada pertengahan September 2008 dan dimulai karena Subprime Mortgage di Amerika Serikat tersebut berdampak pada kinerja industri asuransi di Indonesia selama tahun 2008 sampai 2009. Akibat krisis ini dimana harga saham jatuh tajam, berdampak pada turunnya harga unit link, pernurunan harga unit hampir mencapai $60 \%$, akibatnya banyak investor yang hasil investasinya tidak seperti yang diharapkan.

Penilaian saham dapat dilakukan dengan Price Earning
Ratio (PER) dan Price to Book Value (PBV), karena kedua ukuran tersebut sangat berpengaruh terhadap nilai suatu saham. Bagi investor, PER digunakan untuk memprediksi kemampuan perusahaan dalam menghasilkan laba di masa datang. Sedangkan PBV, apabila harga pasar berada di bawah nilai bukunya, investor memandang bahwa perusahaan tersebut tidak cukup potensial.

Hasil usaha yang optimal akan dapat dicapai dengan menggunakan keseluruhan modal perusahaan yang 
diinvestasikan dalam aktiva untuk menghasilkan keuntungan yang terlihat pada Leverage Ratio (LR) perusahaan, sedangkan penghasilan yang tersedia bagi para pemilik atau modal yang diinvestasikan dalam perusahaan diukur dengan Return On Equity (ROE).

Menurut Siamat (1995), rasio PER digunakan secara luas oleh pelaku pasar modal untuk menilai suatu harga saham. Pada prinsipnya PER memberikan indikasi mengenai jangka waktu yang diperlukan untuk mengembalikan dana pada tingkat harga saham dan keuntungan perusahaan pada suatu periode tertentu. Rasio ini menggambarkan kesediaan investor membayar suatu jumlah untuk setiap rupiah perolehan laba perusahaan.

Menurut Darmadji dan Fakhruddin (2001), price earning ratio menggambarkan apresiasi pasar terhadap kemampuan perusahaan dalam menghasilkan laba. PER dihitung dalam satuan kali. Sebagai contoh, jika suatu saham memiliki PER sebesar 10 kali, berarti pasar menghargai 10 kali atas kemampuan perusahaan menghasilkan laba. Bagi investor, semakin kecil PER suatu saham semakin bagus karena saham tersebut termasuk murah.

Menurut Warsono (2001), hubungan sederhana antara laba per lembar saham sekarang atau yang diharapkan dan harga pasar saham sekarang seringkali digunakan baik oleh manajemen maupun pemilik. Rasio ini juga disebut kelipatan laba (earning multiple) dan digunakan untuk menunjukkan bagaimana pasar saham menilai kinerja dan prospek perusahaan. Perhitungan PER dengan membandingkan antara harga per lembar saham dengan laba per lembar saham.

Sedangkan menurut Arifin (2004), untuk menilai murah atau mahalnya sebuah saham biasanya dipergunakan analisis rasio PER (price earning ratio). Semakin rendah hasil PER sebuah saham maka semakin baik atau murah harganya untuk diinvestasikan. PER menjadi rendah nilainya bisa karena harga saham cenderung semakin turun atau karena meningkatnya laba bersih perusahaan. Jadi semakin kecil nilai PER semakin murah indikasi sebuah saham sehingga semakin layak untuk dibeli. 
Secara teoritis PER (price earning ratio) merupakan indikator yang digunakan untuk menentukan apakah harga saham tertentu dinilai terlalu tinggi (overvalued) atau terlalu rendah (undervalued). PER akan mempengaruhi harga saham, hal ini terlihat apabila PER semakin tinggi, maka semakin besar kemungkinan harga saham dinilai terlalu tinggi (overvalued), selanjtnya cepat atau lambat harga saham tersebut di pasar modal akan terkoreksi. Jika PER semakin rendah maka semakin besar kemungkinan harga saham dinilai terlalu rendah (undervalued), selanjutnya cepat atau lambat harga saham tersebut di pasar modal akan terkoreksi. Bentuk penyesuaian adalah, jika penilaian harga saham terlalu tinggi akan mengalami penurunan, sebaliknya jika penilaian harga saham terlalu rendah akan mengalami kenaikan.

\section{METODOLOGI PENELITIAN}

Penelitian ini dilakukan pada perusahaan asuransi yang go publik di Bursa Efek Indonesia. Alasan pemilihan obyek penelitian ini adalah karena banyak hal yang tidak dapat diduga-duga di masa depan maka asuransi pilihan yang tepat dalam hal berjaga-jaga.

Populasi dalam penelitian ini mencakup perusahaan asuransi yang go publik di Bursa Efek Indonesia. Teknik pengambilan sampel yang digunakan adalah teknik purposive sampling yaitu teknik pengambilan sampel berdasarkan pertimbanganpertimbangan tertentu. Pertimbangan tersebut yaitu perusahaan asuransi yang listing di Bursa Efek Indonesia pada tahun 2005-2009 dan memiliki laporan keuangan yang continue selama periode tahun 2005-2009.

Jumlah populasi perusahaan asuransi yang terdaftar pada BEI sampai akhir Desember 2009 berjumlah 11 perusahaan. Dari 11 perusahaan yang terdaftar pada BEI hanya 9 perusahaan yang aktif bertransaksi pada BEI selama periode tahun 2005 - 2009. Perusahaan yang dijadikan sampel dalam penelitian ini berjumlah 9 perusahaan sebagaiman terlihat pada tabel 2 .

Variabel terikat dalam penelitian ini adalah harga saham. Adapun variabel bebas dalam penelitian ini adalah Price Earning Ratio (PER), Leverage Ratio (LR), 
Return On Equity (ROE), Price to $\quad+\beta_{2} \mathrm{X}_{2}+\beta_{3} \mathrm{X}_{3}+\beta_{4} \mathrm{X}_{4}+$ e. Dimana: $\mathrm{Y}$

Book Value (PBV).

= harga saham; $\mathrm{X} 1$ = variabel price

Teknik analisa data yang earning ratio; $\mathrm{X} 2=$ variabel leverage

digunakan dalam penelitian ini adalah ratio; $\mathrm{X} 3$ = variabel return on equity;

Model Regresi Berganda. dengan $\mathrm{X} 4=$ variabel price to book value.

rumus sebagai berikut:Y $=\beta_{0}+\beta_{1} X_{1}$

Tabel 2. Sampel Penelitian

\begin{tabular}{llccccc}
\hline & \multicolumn{3}{c}{ Pang Aktif Bertransaksi } & \\
& & \multicolumn{3}{c}{ Ket } \\
\cline { 2 - 5 } & 2006 & 2007 & 2008 & 2009 & \\
\hline 1. PT. Asuransi Bina Dana Arta Tbk & $\sqrt{n}$ & $\sqrt{ }$ & $\sqrt{ }$ & $\sqrt{ }$ & Aktif \\
2. PT. Asuransi Harta Aman Pratama Tbk & $\sqrt{ }$ & $\sqrt{ }$ & $\sqrt{ }$ & $\sqrt{ }$ & Aktif \\
3. PT. Asuransi Multi Artha Guna Tbk & - & - & $\sqrt{ }$ & $\sqrt{ }$ & Tidak \\
4. PT. Asuransi Bintang Tbk & $\sqrt{ }$ & $\sqrt{ }$ & $\sqrt{ }$ & $\sqrt{ }$ & Aktif \\
5. PT. Asuransi Dayin Mitra Tbk & $\sqrt{ }$ & $\sqrt{ }$ & $\sqrt{ }$ & $\sqrt{ }$ & Aktif \\
6. PT. Asuransi Jasa Tania Tbk & - & - & $\sqrt{ }$ & $\sqrt{ }$ & Tidak \\
7. PT. Asuransi Ramayana Tbk & $\sqrt{ }$ & $\sqrt{ }$ & $\sqrt{ }$ & $\sqrt{ }$ & Aktif \\
8. PT. Lippo General Insurance Tbk & $\sqrt{ }$ & $\sqrt{ }$ & $\sqrt{ }$ & $\sqrt{ }$ & Aktif \\
9. PT. Maskapai Reasuransi Indonesia Tbk & $\sqrt{ }$ & $\sqrt{ }$ & $\sqrt{ }$ & $\sqrt{ }$ & Aktif \\
10. PT. Panin Insurance Tbk & $\sqrt{ }$ & $\sqrt{ }$ & $\sqrt{ }$ & $\sqrt{ }$ & Aktif \\
11. PT. Panin Life Tbk & $\sqrt{ }$ & $\sqrt{ }$ & $\sqrt{ }$ & $\sqrt{ }$ & Aktif
\end{tabular}

Sumber: Bursa Efek Indonesia tahun 2009

PEMBAHASAN

Penelitian ini dilakukan untuk menguji pengaruh variabel-variabel fundamental yaitu Price Earning Ratio (PER), Leverage Ratio (LR), Return On Equity (ROE) dan Price to Book Value (PBV) terhadap harga saham. Data diperoleh dari laporan keuangan perusahaan asuransi yang dipublikasikan secara lengkap di Bursa Efek Indonesia. Data laporan keuangan perusahaan asuransi merupakan sumber dalam perhitungan nilai faktor fundamental mulai tahun 2005-2009.

$$
\text { Price earning ratio }
$$

memperlihatkan seberapa besar harga yang para investor bersedia untuk membayar setiap rupiah laba yang dilaporkan. Besarnya hasil perhitungan rasio PER menunjukkan harga setiap unit yang berlaku untuk setiap laba atau pendapatan per lembar sahamnya.

Berdasarkan tabel 3, maka nilai PER yang tertinggi pada tahun 2005 adalah PT. PNIN Tbk sebesar Rp 
15,47 per lembar saham sedangkan yang terendah adalah PT. LPGI Tbk sebesar Rp. 2,72 per lembar saham. Pada tahun 2006, nilai PER yang tertinggi adalah PT. ASBI sebesar Rp 67,57 per lembar saham dan nilai yang terendah adalah PT. ASRM Tbk sebesar Rp 3,69 per lembar saham. Pada tahun 2007, nilai PER yang tertinggi adalah PT. AHAP Tbk sebesar Rp 53,29 per lembar saham sedangkan yang terendah adalah PT. PNIN Tbk sebesar Rp 3,77 per lembar saham. Pada tahun 2008, nilai PER yang tertinggi adalah PT. AHAP Tbk sebesar Rp 16,77 per lembar saham sedangkan yang terendah adalah PT. PNIN Tbk sebesar Rp 1,91 per lembar saham. Pada tahun 2009, nilai PER yang tertinggi adalah PT.
ASBI Tbk sebesar Rp 13,89 per lembar saham sedangkan yang terendah adalah PT. PNIN Tbk sebesar Rp 2,57 per lembar saham.

Rata-rata nilai PER mulai tahun 2005-2009 yang tertinggi adalah PT. ASBI Tbk sebesar Rp 21,65 per lembar saham sedangkan yang terendah adalah PT. ASRM Tbk sebesar Rp 3,55 per lembar saham. Arti dari nilai rata-rata PER milik PT. ASBI Tbk sebesar Rp 21,65 per lembar saham adalah nilai ini menunjukkan bahwa harga setiap laba per lembar sahamnya adalah $\mathrm{Rp} 21,65$ atau laba yang diterima tiap lembarnya sebesar Rp 21,65. Begitu juga untuk PT. ASRM Tbk sebesar Rp 3,55 per lembar sahamnya.

Tabel 3. Price Earning Ratio Perusahaan-perusahaan Asuransi Periode 2005-2009

\begin{tabular}{lcccccc}
\hline \multirow{2}{*}{ Perusahaan } & \multicolumn{5}{c}{ Tahun } & Rata- \\
\cline { 2 - 5 } & 2005 & 2006 & 2007 & 2008 & 2009 & Rata \\
\hline PT. ABDA & 9.21 & 34.00 & 4.69 & 3.72 & 3.18 & 10.96 \\
PT. AHAP & 12.90 & 10.85 & 53.29 & 16.77 & 7.83 & 20.33 \\
PT. ASBI & 11.80 & 67.57 & 4.46 & 10.51 & 13.89 & 21.65 \\
PT. ASDM & 5.40 & 10.83 & 18.33 & 4.82 & 5.99 & 9.07 \\
PT. ASRM & 3.79 & 3.69 & 3.90 & 2.77 & 3.58 & 3.55 \\
PT. LPGI & 2.72 & 25.77 & 5.26 & 4.59 & 3.70 & 8.41 \\
PT. MREI & 14.79 & 4.95 & 5.64 & 2.60 & 3.49 & 6.29 \\
PT. PNIN & 15.47 & 3.75 & 3.77 & 1.91 & 2.57 & 5.49 \\
PT. PNLF & 8.22 & 12.23 & 10.49 & 5.43 & 7.23 & 8.72 \\
\hline
\end{tabular}

Sumber : Bursa Efek Indonesia tahun 2009, data diolah
Adapun perhitungan leverage mengenai struktur modal yang ratio dapat memberikan gambaran dimiliki perusahaan dan dapat dilihat 
tingkat resiko tidak tertagihnya suatu hutang.

Berdasarkan tabel 4, nilai LR tertinggi pada tahun 2005 adalah PT. ASRM Tbk sebesar 59,01\% sedangkan yang terendah adalah PT. LPGI Tbk sebesar 24,91\%. Pada tahun 2006 nilai LR tertinggi adalah PT. ASRM Tbk sebesar 60,04\% sedangkan yang terendah adalah PT. LPGI Tbk sebesar 22,30\%. Pada tahun 2007 nilai LR yang tertinggi adalah PT. ABDA Tbk sebesar $61,32 \%$ dan yang nilai LR yang terendah adalah PT. LPGI sebesar 18,25\%. Pada tahun 2008 nilai LR yang tertinggi adalah PT. ABDA Tbk sebesar $71,80 \%$ dan terendah adalah PT. LPGI Tbk sebesar 18,33\%. Pada tahun 2009 nilai LR yang tertinggi adalah PT. ABDA Tbk sebesar $76,07 \%$ dan terendah adalah PT. LPGI Tbk sebesar 21,54\%.
Rata-rata nilai LR mulai tahun 2005-2009 yang tertinggi adalah PT. ABDA Tbk sebesar 62,38\% dan yang terendah adalah PT. LPGI Tbk sebesar $21,07 \%$. Arti nilai rata-rata LR sebesar 62,38\% milik PT. ABDA Tbk menunjukkan bahwa perusahaan dengan leverage ratio tinggi sehingga mempunyai resiko yang besar tetapi juga memiliki kesempatan untuk memperoleh laba yang tinggi.

Sedangkan nilai rata-rata LR milik PT. LPGI Tbk sebesar 21,07\% merupakan perusahaan dengan resiko leverage rendah memiliki resiko rugi kecil jika kondisi ekonomi sedang menurun, tetapi juga memiliki hasil pengembalian yang rendah jika kondisi ekonomi sedang membaik.

Analisis berikutnya yaitu Return on equity yang mengukur kemampuan perusahaan memperoleh laba yang tersedia bagi pemegang saham perusahaan.

Tabel 4. Leverage Ratio Perusahaan-perusahaan Asuransi Periode 2005-2009

\begin{tabular}{lcccccc}
\hline \multirow{2}{*}{ Perusahaan } & \multicolumn{5}{c}{ Tahun } & \multirow{2}{*}{$\begin{array}{c}\text { Rata- } \\
\text { Rata }\end{array}$} \\
\cline { 2 - 6 } & 2005 & 2006 & 2007 & 2008 & 2009 & Rat \\
\hline PT. ABDA & 51.11 & 51.62 & 61.32 & 71.80 & 76.07 & 62.38 \\
PT. AHAP & 36.14 & 32.44 & 41.58 & 42.25 & 47.62 & 40.01 \\
PT. ASBI & 57.35 & 52.51 & 59.51 & 57.96 & 51.44 & 55.75 \\
PT. ASDM & 56.03 & 58.62 & 55.66 & 60.07 & 57.01 & 57.48 \\
PT. ASRM & 59.01 & 60.04 & 58.39 & 64.40 & 65.16 & 61.40 \\
PT. LPGI & 24.91 & 22.30 & 18.25 & 18.33 & 21.54 & 21.07 \\
\hline
\end{tabular}




\begin{tabular}{lllllll}
\hline PT. MREI & 53.93 & 45.44 & 50.05 & 55.62 & 57.83 & 52.57 \\
PT. PNIN & 26.03 & 27.35 & 33.80 & 25.84 & 30.27 & 28.66 \\
PT. PNLF & 31.92 & 28.60 & 35.86 & 26.98 & 32.25 & 31.12 \\
\hline
\end{tabular}

Sumber : Bursa Efek Indonesia tahun 2009, data diolah

Tabel 5. Return On Equity Perusahaan-Perusahaan Asuransi Periode 20052009

\begin{tabular}{lcccccc}
\hline \multirow{2}{*}{ Perusahaan } & \multicolumn{5}{c}{ Tahun } & $\begin{array}{c}\text { Rata- } \\
\text { Rata }\end{array}$ \\
\cline { 2 - 5 } & 2005 & 2006 & 2007 & 2008 & 2009 & Rat \\
\hline PT. ABDA & 7.90 & 1.57 & 12.35 & 11.86 & 21.01 & 10.94 \\
PT. AHAP & 10.08 & 7.60 & 4.53 & 5.56 & 13.79 & 8.31 \\
PT. ASBI & 4.31 & 1.49 & 16.72 & 7.45 & 4.17 & 6.83 \\
PT. ASDM & 8.11 & 3.00 & 2.90 & 4.88 & 6.81 & 5.14 \\
PT. ASRM & 17.96 & 16.68 & 15.23 & 15.23 & 17.39 & 16.50 \\
PT. LPGI & 6.21 & 0.54 & 2.86 & 2.04 & 4.78 & 3.29 \\
PT. MREI & 4.50 & 10.86 & 12.83 & 18.43 & 22.27 & 13.78 \\
PT. PNIN & 2.84 & 13.65 & 13.14 & 11.32 & 12.52 & 10.69 \\
PT. PNLF & 11.19 & 8.77 & 10.62 & 8.52 & 9.71 & 9.76 \\
\hline
\end{tabular}

Sumber : Bursa Efek Indonesia tahun 2009, data diolah

Berdasarkan tabel 5, maka nilai ROE yang tertinggi pada tahun 2005 adalah PT. ASRM Tbk sebesar $17,96 \%$ sedangkan nilai yang terendah adalah PT. PNIN Tbk sebesar 2,84\%. Pada tahun 2006, nilai ROE yang tertinggi adalah PT. ASRM Tbk sebesar $16,68 \%$ dan nilai yang terendah adalah PT. LPGI Tbk sebesar $0,54 \%$. Pada tahun 2007, nilai ROE yang tertinggi adalah PT. ASBI Tbk sebesar $16,72 \%$ sedangkan nilai yang terendah adalah PT. LPGI Tbk sebesar 2,86\%. Pada tahun 2008, nilai ROE yang tertinggi adalah PT. MREI Tbk sebesar 18,43\% dan nilai yang terendah adalah PT. LPGI Tbk sebesar 2,04\%. Pada tahun 2009, nilai ROE yang tertinggi adalah PT. MREI Tbk sebesar 22,27\% dan nilai yang terendah adalah PT. ASBI Tbk sebesar $4,17 \%$.

Rata-rata nilai ROE mulai tahun 2005-2009 yang tertinggi adalah PT. ASRM Tbk sebesar 16,50\% sedangkan nilai ROE yang terendah adalah PT. LPGI Tbk sebesar 3,29\%. Arti nilai rata-rata ROE sebesar $16,50 \%$ yang dimiliki oleh PT. ASRM Tbk dan 6,01\% milik PT. LPGI Tbk menunjukkan kemampuan perusahaan dalam memperoleh laba dari modal sendiri yang tersedia 
untuk para pemegang saham perusahaan.

Analisis berikutnya yaitu Price to Book Value (PBV), Rasio ini menunjukkan seberapa jauh sebuah perusahaan mampu menciptakan nilai perusahaan relatif terhadap jumlah modal yang diinvestasikan.

Berdasarkan tabel 6, maka nilai PBV yang tertinggi pada tahun 2005 adalah PT. AHAP Tbk sebesar Rp 1,30 per lembar saham sedangkan yang terendah adalah PT. LPGI Tbk sebesar Rp. 0,17 per lembar saham. Pada tahun 2006, nilai PBV yang tertinggi adalah PT. PNLF sebesar Rp 1,07 per lembar saham dan nilai yang terendah adalah PT. LPGI Tbk sebesar Rp 0,14 per lembar saham. Pada tahun 2007, nilai PBV yang tertinggi adalah PT. AHAP Tbk sebesar Rp 2,41 per lembar saham sedangkan yang terendah adalah PT. LPGI Tbk sebesar Rp 0,15 per lembar saham. Pada tahun 2008, nilai PBV yang tertinggi adalah PT. AHAP Tbk sebesar Rp 0,93 per lembar saham sedangkan yang terendah adalah PT. LPGI Tbk sebesar Rp 0,09 per lembar saham. Pada tahun 2009, nilai PBV yang tertinggi adalah PT. AHAP Tbk sebesar Rp 1,08 per lembar saham sedangkan yang terendah adalah PT. LPGI Tbk sebesar Rp 0,18 per lembar saham.

Rata-rata nilai PBV mulai tahun 2005-2009 yang tertinggi adalah PT. AHAP Tbk sebesar Rp 1,31 per lembar saham sedangkan yang terendah adalah PT. LPGI Tbk sebesar Rp 0,15 per lembar saham. Arti dari nilai rata-rata PBV milik PT. AHAP Tbk sebesar Rp 1,31 per lembar saham yaitu menunjukkan semakin berhasil perusahaan menciptakan nilai bagi pemegang saham, dan sebaliknya $\mathrm{Rp} 0,15$ per lembar saham milik PT. LPGI.

Adapun harga saham yang digunakan dalam penelitian ini adalah harga saham tahunan dari perusahaan sampel yang diambil di Bursa Efek Indonesia selama 5 tahun, yaitu tahun 2005 - 2009.

Berdasarkan tabel 7, maka harga saham yang tertinggi pada perusahaan-perusahaan asuransi tahun 2005 adalah PT. ASRM Tbk sebesar Rp 1.000 per lembar saham sedangkan harga yang terendah adalah pada PT. AHAP Tbk dan PT. PNLF Tbk sebesar Rp 135 per lembar saham. Pada tahun 2006, perusahaan yang harga sahamnya tertinggi adalah 
PT. ASRM Tbk sebesar Rp 1.010 per lembar saham dan harga saham yang terendah adalah PT. AHAP Tbk sebesar Rp 90 per lembar saham.

Harga saham pada perusahaan- perusahaan asuransi pada tahun 2007 yang tertinggi adalah PT. ASRM Tbk sebesar Rp 790 per lembar saham

Tabel 6. Price to Book Value Perusahaan-Perusahaan Asuransi Periode 20052009

\begin{tabular}{lcccccc}
\hline \multirow{2}{*}{ Perusahaan } & \multicolumn{5}{c}{ Tahun } & Rata- \\
\cline { 2 - 5 } & 2005 & 2006 & 2007 & 2008 & 2009 & Rata \\
\hline PT. ABDA & 0.73 & 0.53 & 0.58 & 0.44 & 0.67 & 0.59 \\
PT. AHAP & 1.30 & 0.82 & 2.41 & 0.93 & 1.08 & 1.31 \\
PT. ASBI & 0.49 & 1.01 & 0.75 & 0.78 & 0.58 & 0.72 \\
PT. ASDM & 0.44 & 0.33 & 0.53 & 0.24 & 0.41 & 0.39 \\
PT. ASRM & 0.60 & 0.61 & 0.59 & 0.43 & 0.62 & 0.57 \\
PT. LPGI & 0.17 & 0.14 & 0.15 & 0.09 & 0.18 & 0.15 \\
PT. MREI & 0.67 & 0.54 & 0.72 & 0.48 & 0.78 & 0.64 \\
PT. PNIN & 0.44 & 0.51 & 0.54 & 0.22 & 0.32 & 0.41 \\
PT. PNLF & 0.92 & 1.07 & 1.18 & 0.46 & 0.70 & 0.87 \\
\hline
\end{tabular}

Sumber : Bursa Efek Indonesia tahun 2009, data diolah

Tabel 7. Harga Saham Perusahaan-Perusahaan Asuransi Periode 2005-2009

\begin{tabular}{lcccccc}
\hline \multirow{2}{*}{ Perusahaan } & \multicolumn{5}{c}{ Tahun } & Rata- \\
\cline { 2 - 5 } & 2005 & 2006 & 2007 & 2008 & 2009 & Rata \\
\hline PT. ABDA & 200 & 220 & 220 & 200 & 300 & 228 \\
PT. AHAP & 135 & 90 & 225 & 86 & 114 & 130 \\
PT. ASBI & 370 & 340 & 345 & 400 & 355 & 362 \\
PT. ASDM & 240 & 175 & 190 & 114 & 180 & 179.8 \\
PT. ASRM & 1000 & 1010 & 790 & 610 & 900 & 862 \\
PT. LPGI & 265 & 340 & 540 & 340 & 455 & 388 \\
PT. MREI & 165 & 150 & 225 & 174 & 285 & 199.8 \\
PT. PNIN & 265 & 280 & 330 & 149 & 255 & 255.8 \\
PT. PNLF & 135 & 165 & 195 & 83 & 140 & 143.6 \\
\hline
\end{tabular}

Sumber : Bursa Efek Indonesia tahun 2009, data diolah

Sedangkan yang terendah saham yang terendah adalah PT. adalah PT. ASDM Tbk sebesar Rp PNLF Tbk sebesar Rp 83 per lembar 190 per lembar saham. Pada tahun saham. Pada tahun 2009, harga saham 2008, harga saham yang tertinggi yang tertinggi adalah PT. ASRM Tbk adalah PT. ASRM Tbk sebesar Rp sebesar Rp 900 per lembar saham dan 610 per lembar saham dan harga harga saham yang terendah adalah 
PT. AHAP Tbk sebesar Rp 114 per lembar saham.

Rata-rata harga saham mulai tahun 2005-2009 pada perusahaanperusahaan asuransi yang tertinggi adalah PT. ASRM Tbk sebesar Rp 862 sedangkan harga saham yang terendah adalah PT. AHAP Tbk sebesar Rp 130 per lembar saham. Arti rata-rata harga saham sebesar $\mathrm{Rp}$ 862 yang dimiliki oleh PT. ASRM Tbk adalah menggambarkan nilai dari suatu saham yang terbentuk dari penawaran dan permintaan saham di pasar surat berharga sebesar Rp 862, begitu juga harga saham milik PT. AHAP Tbk sebesar Rp 130.

Adapun pengujian seberapa besar pengaruh PER, LR, ROE dan PBV terhadap harga saham perusahaan asuransi dapat dilihat melalui hasil regresi yang meliputi penyajian hasil regresi hubungan antara variabel dependent (yang dipengaruhi) dengan variabel independent (yang mempengaruhi), dengan tujuan untuk mengetahui nilai-nilai regresi dari masing-masing variabel sehingga dapat diketahui pengaruhnya. Adapun hasil regresi linear berganda dengan menggunakan metode kuadrat terkecil biasa (ordinary least square) dapat dilihat pada tabel 8 .

Hasil regresi yang ditampilkan pada tabel 8 menunjukkan persamaan regresi linear berganda antara harga saham dengan PER, LR, ROE dan PBV. Adapun pembentukan model dari persamaan regresi linear berganda yaitu $\mathrm{Y}=2,584+0,556 \mathrm{X}_{1}$ $+0,008 X_{2}+0,100 X_{3}-0,818 X_{4}+$ e. Berdasarkan model persamaan regresi linear berganda dapat dijelaskan bahwa Konstanta $\left(\beta_{0}\right)$ sebesar 2,584; berarti nilai harga saham (Y) sebesar 2,584 pada saat PER $\left(\mathrm{X}_{1}\right), \mathrm{LR}\left(\mathrm{X}_{2}\right)$, $\operatorname{ROE}\left(\mathrm{X}_{3}\right)$ dan PBV $\left(\mathrm{X}_{4}\right)$ sama dengan nol. PER $\left(\beta_{1}\right)$ sebesar 0,556 ; berarti koefisien regresi variabel PER $\left(\mathrm{X}_{1}\right)$ sebesar 0,556, berarti ada pengaruh positif antara PER $\left(\mathrm{X}_{1}\right)$ terhadap harga saham (Y) sebesar 0,556. LR $\left(\beta_{2}\right)$ sebesar 0,008 ; berarti koefisien regresi variabel $\mathrm{LR}\left(\mathrm{X}_{2}\right)$ sebesar 0,008, berarti ada pengaruh positif antara LR $\left(\mathrm{X}_{2}\right)$ terhadap harga saham (Y) sebesar 0,008. ROE $\left(\beta_{3}\right)$ sebesar 0,100 ; berarti koefisien regresi variabel $\operatorname{ROE}\left(\mathrm{X}_{3}\right)$ sebesar 0,100 , berarti ada pengaruh positif antara $\operatorname{ROE}\left(\mathrm{X}_{3}\right)$ terhadap harga saham $(\mathrm{Y})$ sebesar 0,100. PBV $\left(\beta_{4}\right)$ sebesar 0,818; berarti koefisien regresi 
variabel PBV $\left(\mathrm{X}_{4}\right)$ sebesar $-0,818, \quad \mathrm{PBV}\left(\mathrm{X}_{4}\right)$ terhadap harga saham $(\mathrm{Y})$ berarti ada pengaruh negatif antara sebesar $-0,818$.

Tabel 8. Hasil Regresi Linear Berganda

\begin{tabular}{cccccc}
\hline Variabel Bebas & Keterangan & Koefisien & Std, Error & t-Statistik & Prob \\
\hline C & Konstan & 2,584 & 0,988 & 2,613 & 0,012 \\
X1 & PER & 0,556 & 0,264 & 2,108 & 0,041 \\
X2 & LR & 0,008 & 0,006 & 1,318 & 0,194 \\
X3 & ROE & 0,100 & 0,037 & 2,654 & 0,011 \\
X4 & PBV & $-0,818$ & 0,260 & $-3,141$ & 0,003
\end{tabular}

\begin{tabular}{ccc}
\multicolumn{3}{c}{ R-squared 0,280 } \\
\hline Uji $\quad$ regresi $\quad$ F-statistik
\end{tabular}

F-Statistik 3,896

menunjukkan hasil analisa regresi

5\% maka Ho diterima dan Ha ditolak

variabel independent secara bersamayang berarti bahwa secara statistik sama terhadap variabel dependent. variabel LR memiliki pengaruh Dari hasil analisa menunjukkan positif dan tidak signifikan secara bahwa F-hitung statistik sebesar parsial terhadap harga saham. Nilai t3,896 > F-tabel statistik 2,61, dengan tingkat $\alpha=5 \%$ maka Ha diterima dan Ho ditolak. Sehingga dapat dijelaskan bahwa secara statistik variabel independent secara bersama-sama berpengaruh signifikan terhadap variabel dependent.

Adapun nilai t-hitung $\mathrm{X}_{1}(\mathrm{PER})$ sebesar 2,108> nilai t-tabel sebesar 2,021 dengan $\mathrm{df}=40$ dan $\alpha=5 \%$ maka Ho ditolak dan Ha diterima yang berarti bahwa secara statistik variabel PER memiliki pengaruh positif dan signifikan secara parsial terhadap harga saham. Nilai t-hitung $\mathrm{X}_{2}(\mathrm{LR})$ sebesar 1,318 < nilai t-tabel sebesar 2,021 dengan $\mathrm{df}=40$ dan $\alpha=$ hitung $\mathrm{X}_{3}(\mathrm{ROE})$ sebesar 2,654 > nilai t-tabel sebesar 2,021 dengan $\mathrm{df}=40$ dan $\alpha=5 \%$ maka Ho ditolak dan Ha diterima yang berarti bahwa secara statistik variabel ROE memiliki pengaruh positif dan signifikan secara parsial terhadap harga saham. Nilai thitung $\mathrm{X}_{4}(\mathrm{PBV})$ sebesar $-3,141>$ nilai t-tabel sebesar $\quad-2,021$ dengan $\mathrm{df}=40$ dan $\alpha=5 \%$ maka Ho ditolak dan Ha diterima yang berarti bahwa secara statistik variabel PBV memiliki pengaruh negatif dan signifikan secara parsial terhadap harga saham.

Berdasarkan hasil regresi, dapat diketahui bahwa $\mathrm{R}$ square sebesar 0,280, ini menunjukkan bahwa 
sebesar $28 \%$ variabel independent yang berupa PER, LR, ROE dan PBV mampu menjelaskan variabel dependen yang berupa harga saham. Dapat juga dikatakan bahwa variabelvariebel independent tersebut mempunyai pengaruh sebesar $28 \%$ terhadap harga saham, sedangkan sisanya sebesar $72 \%$ dijelaskan oleh variabel-variabel lain selain ke empat variabel independent tersebut (dijelaskan oleh variabel lainnya yang tidak termasuk didalam model).

Langkah selanjutnya yaitu pengujian asumsi klasik, pengujian ini dimaksudkan untuk mendeteksi mengenai ada tidaknya masalah multikolinearitas, heteroskedastisitas, autokorelasi, dan normalitas dalam hasil estimasi. Dengan terjadinya penyimpangan terhadap asumsi klasik tersebut diatas akan menyebabkan uji statistik (uji t maupun uji F) yang dilakukan menjadi tidak valid dan secara statistik akan mengacaukan kesimpulan yang diperoleh. Berdasarkan hasil uji asumsi klasik yang dilakukan, dapat diketahui bahwa model dinyatakan lolos.

Variabel price earning ratio $\left(\mathrm{X}_{1}\right)$ berpengaruh positif terhadap harga saham, yaitu sebesar 0,556.
Artinya jika variabel price earning ratio meningkat 1 kali maka harga saham akan mengalami kenaikan sebesar 0,556 dengan anggapan variabel leverage ratio $\left(\mathrm{X}_{2}\right)$, return on equity $\left(\mathrm{X}_{3}\right)$ dan price to book value $\left(\mathrm{X}_{4}\right)$ tetap. Hal ini menggambarkan bahwa semakin tinggi PER, maka penghargaan pasar akan saham perusahaan tersebut akan semakin tinggi sehingga harga saham cenderung akan naik. Akan tetapi bagi investor yang ingin membeli saham suatu perusahaan, semakin kecil PER suatu saham akan semakin baik karena harga saham tersebut murah.

Variabel leverage ratio $\left(\mathrm{X}_{2}\right)$ berpengaruh positif terhadap harga saham, yaitu sebesar 0,008. Artinya jika variabel leverage ratio meningkat $1 \%$ maka harga saham akan mengalami kenaikan sebesar 0,008 dengan anggapan variabel price earning ratio $\left(\mathrm{X}_{1}\right)$, return on equity $\left(\mathrm{X}_{3}\right)$ dan price to book value $\left(\mathrm{X}_{4}\right)$ tetap. Hal ini menggambarkan bahwa semakin tinggi penggunaan leverage semakin besar jumlah hutang yang digunakan untuk menambah asset bagi perusahaan. Dengan bertambahnya asset perusahaan maka 
profitabilitas perusahaan akan meningkat (keuntungan perusahaan meningkat).

Variabel return on equity $\left(\mathrm{X}_{3}\right)$ berpengaruh positif terhadap harga saham, yaitu sebesar 0,100. Artinya jika variabel return on equtiy meningkat $1 \%$ maka harga saham akan mengalami kenaikan sebesar 0,100 dengan anggapan variabel price earning ratio $\left(\mathrm{X}_{1}\right)$, leverage ratio $\left(\mathrm{X}_{2}\right)$ dan price to book value $\left(\mathrm{X}_{4}\right)$ tetap.

Adanya pengaruh positif ROE terhadap harga saham mengindikasikan bahwa kinerja perusahaan asuransi semakin efisien dalam menggunakan modal sendiri untuk menghasilkan laba atau keuntungan bersih sehingga rasio ROE perusahaan semakin tinggi. Rasio ROE yang tinggi cenderung meningkatkan minat investor terhadap saham karena menganggap perusahaan tersebut mempunyai prospek yang baik dalam meningkatkan laba. Apabila minat investor meningkat terhadap suatu saham, maka harga saham tersebut akan meningkat.

Variabel price to book value $\left(\mathrm{X}_{4}\right)$ berpengaruh negatif terhadap harga saham, yaitu sebesar $-0,818$. Artinya jika variabel price to book value meningkat $1 \%$ maka harga saham akan mengalami penurunan sebesar 0,818 dengan anggapan variabel price earning ratio $\left(\mathrm{X}_{1}\right)$, leverage ratio $\left(\mathrm{X}_{2}\right)$ dan return on equity $\left(\mathrm{X}_{3}\right)$ tetap.

Hasil penelitian ini memberikan arti bahwa PBV tidak memiliki pengaruh terhadap harga saham walaupun pada dasarnya, semakin tinggi rasio PBV menunjukkan bahwa harga suatu saham kian dinilai tinggi oleh pasar sebanding dengan nilai buku perusahaannya. Namun demikian, kian tinggi PBV berarti harga suatu saham sebenarnya sudah makin mahal.

\section{PENUTUP}

Berdasarkan hasil analisis data dan pembahasan hasil penelitian yang telah dilakukan, maka dapat diperoleh kesimpulan bahwa PER, LR, ROE dan PBV secara bersama-sama berpengaruh signifikan terhadap harga saham. Hal ini dapat dilihat dari uji $F$ secara simultan yang ditunjukkan dengan nilai $\mathrm{F}$ hitung $3.896>$ F tabel 2.61. Hasil uji secara parsial variabel independent terhadap 
variabel dependent menunjukkan bahwa PER dan ROE secara statistik memiliki pengaruh positif dan signifikan terhadap harga saham, PBV secara statistik memiliki pengaruh negatif dan signifikan terhadap harga saham sedangkan LR secara statistik memiliki pengaruh positif tetapi tidak signifikan terhadap harga saham.

Berdasarkan hasil uji statistik menunjukkan variabel-variabel independent tersebut mempunyai pengaruh sebesar $28 \%$ terhadap harga saham, sedangkan sisanya sebesar $72 \%$ dijelaskan oleh variabel-variabel lain selain keempat variabel independent tersebut.

\section{DAFTAR PUSTAKA}

Agus Sartono. 2001. Manajemen Keuangan Teori dan Aplikasi. Edisi Empat. Penerbit BPFE. Yogyakarta.

Algifari. 1996. Analisis Statistik Untuk Bisnis. Cetakan Pertama. BPFE. Yogyakarta.

Arifin, Ali. 2001. Membaca Saham. Edisi Kedua. Andi Offiset. Yogyakarta.

Ghozali Farhan. 2005. Faktor-Faktor Yang Mempengaruhi Harga Saham Pada Perusahaan Manufaktur (Kelompok Food \& Beverages) di Bursa Efek
Surabaya. Jurnal Aplikasi Manajemen Volume 3 Nomor 3.

Gujarati, Damodar N. dan Dawn C. Porter. 2010. Dasar-Dasar Ekonometrika. Edisi Lima. Salemba Empat. Jakarta.

Halim, A. 2003. Analisis Investasi. Edisi Pertama. Penerbit Salemba Empat. Jakarta.

Hinsa Siahaan. 2003. Analisa Saham Dengan Menggunakan Gordon Model. Kajian Ekonomi dan Keuangan Vol.7 No.1.

Isa Pujianto. 2004. Analisis FaktorFaktor Yang Mempengaruhi Harga Saham Perusahaan Manufaktur Di Bursa Efek Jakarta (Pendekatan PER). Skripsi pada Universitas Muhammadiyah Malang.

Jogiyanto. 2003. Teori Portofolio dan Analisa Investasi. BPFE. Yogyakarta.

Lukman Syamsudin. 1995. Manajemen Keuangan. Cetakan kedua. Penerbit BPFE. Yogyakarta.

Mahmud M. Hanafi dan Abdul halim. 2003. Analisis Laporan Keuangan. Edisi Revisi. Penerbit UPP AMP YKPN. Yogyakarta.

M Fakhrudin dan M Shopian Hadianto. 2001. Perangkat Dan Teknik Analisis Investasi Pasar Modal. PT. Elex Media Komputindo. Jakarta. 
Nicky Nathaniel SD, ST. 2008. Analisis Faktor-Faktor Yang Mempengaruhi Return Saham (Studi Pada Saham-Saham Real Estate dan Property di Bursa Efek Indonesia Periode 2004-2006). Skripsi pada Universitas Diponegoro Semarang.

Rusdin. 2005. Pasar Modal. Penerbit Alfabet. Bandung

Siamat, D. 2000. Manajemen Lembaga Keuangan. Penerbit FE UI. Jakarta.

Siti Isabanah. 2004. Analisis PER Dalam Rangka Penilaian Kewajaran Harga Saham Farmasi Yang Go Publik di $B E J$. Skripsi pada Universitas Muhammadiyah Malang.

Sudarmi, Puji. 1996. Analisis FaktorFaktor Fundamental Yang
Mempengaruhi Harga Saham Perusahaan Manufaktur Di BEJ (Pendekatan PER). Skripsi pada Universitas Muhammadiyah Malang.

Sumodiningrat, Gunawan. 1994. Ekonometrika Pengantar. Edisi Pertama. BPFE. Yogyakarta.

Sunariyah. 2003. Pengantar Pengetahuan Pasar Modal. Edisi Ketiga. UPP_AMP YKPN. Yogyakarta.

Tjiptono Darmadji dan H. M. Fakhruddin. 2001. Pasar Modal di Indonesia : Pendekatan Tanya Jawab. Penerbit Salemba Empat. Jakarta.

Undang-undang Pasar Modal No. 8 Tahun 1995. 